\title{
MOTIVASI BELAJAR, KEMANDIRIAN BELAJAR DAN PRESTASI BELAJAR MAHASISWA BEASISWA BIDIKMISI DI UPBJJ UT BANDUNG
}

\author{
Angga Sucitra Hendrayana (angga-sucitra@ut.ac.id) \\ Dina Thaib \\ Raja Rosnenty \\ UPBJJ-UT Bandung
}

\begin{abstract}
This research aims to know level of learning motivation, independent learning and academic achievement Bidikmisi student scholarships at Indonesian Open University Regional office Bandung. This research is adescriptive research by taking samples of throughout Bidikmisi student scholarships at Indonesian Open University Regional Office Bandung consisting of study program in Accounting, Biology and Regional Planning City of the studentas much as 94 students at Registration Period 2013.2. The data in this study are learning motivation, independent learning, and the grade-point average (GPA). The data were analyzed descriptively to describe the level of learning motivation, independent learning, and gradepoint average (GPA). The result of research shown that the average level of learning motivation are included in the category of very high. Independent learning showed that the average independent learning of students in the high category and the grade-point average (GPA) between 1.75 to 3.85withan average GPAof 2.70.
\end{abstract}

Keywords: independent learning, Learning motivation, student performance

\begin{abstract}
ABSTRAK
Penelitian ini merupakan penelitian deskriptif dengan mengambil sampel seluruh mahasiswa beasiswa Bidikmisi di UPBJJ UT Bandung yang terdiri dari program studi Akuntansi, Biologi dan Perencanaan Wilayah Kota Masa registrasi 2013.2 sebanyak 94 mahasiswa. Variabel dalam penelitian ini adalah motivasi belajar, kemandirian belajar, dan indeks prestasi belajar (IPK). Analisis data dilakukan secara deskriptif untuk mengetahui gambaran tingkat motivasi belajar, kemandirian belajar, dan IPK mahasiswa. Hasil penelitian menunjukkan bahwa motivasi belajar termasuk dalam kategori sangat tinggi, dan kemandirian belajar rata rata termasuk dalam kategori tinggi, dan IPK berada dikisaran antara 1,75-3,85 dengan rata-rata IPK 2,70.
\end{abstract}

Kata kunci: indeks prestasi belajar, kemandirian belajar, motivasi belajar

Bidikmisi adalah program pemerintah melalui Direktorat Jendral Pendidikan Tinggi (Ditjen Dikti) Kementerian Pendidikan dan Kebudayaan Republik Indonesia yang diluncurkan pada tahun 2010. Program ini merupakan upaya pemerintah dalam memberikan akses pendidikan khususnya pendidikan tinggi sesuai dengan UUD 1945 pasal 31 yang isinya mengatur mengenai hak dan kewajiban sebagai warga negara Republik Indonesia khususnya dalam hal dunia pendidikan dan 
kebudayaan serta menegaskan bahwa Negara dalam hal ini pemerintah harus memberikan perhatian khusus pada dunia pendidikan Indonesia.

Program Beasiswa Bidikmisi ini dicanangkan untuk lulusan pendidikan jenjang menengah yang berprestasi baik dalam bidang bidang akademik/kurikuler, ko-kurikuler, maupun ekstrakurikuler yang tidak mampu untuk melanjutkan ke jenjang pendidikan tinggi karena disebabkan tidak ada biaya atau berasal dari keluarga yang kurang mampu. Tujuan dari pelaksanaan program Beasiswa Bidikmisi adalah untuk memutus rantai kemiskinan dengan memberikan beasiswa kepada siswa berprestasi dan dari keluarga miskin untuk menjadi seseorang yang berhasil, kemudian membawa keluarga mereka untuk keluar dari kemiskinan.

Universitas Terbuka (UT) telah mengelola beberapa program beasiswa yang berasal dari Kemdikbud dan Mitra UT. Masing-masing program beasiswa memiliki tujuan dan persyaratan tersendiri. Mulai tahun 2012 UT diberi kesempatan oleh Ditjen Dikti untuk merekrut mahasiswa dari lulusan SLTA dua tahun terakhir, guna memperoleh beasiswa Bidikmisi. Alokasi bantuan studi Bidikmisi UT Tahun 2013 sebanyak 1000 mahasiswa, yang dibagi menjadi 40 (empat puluh) kelas Program Sarjana non-Keguruan (FISIP, FMIPA, atau FEKON).

Dengan adanya Program Beasiswa Bidikmisi tersebut sejalan dengan tujuan didirikannya UT yaitu:

1. Memberikan kesempatan yang luas bagi wrga negara Indonesia dan warga negara asing, dimanapun tempat tinggalnya, untuk memperoleh pendidikan tinggi;

2. Memberikan layanan pendidikan tinggi bagi mereka, yang karena bekerja atau karena alasan lain, tidak dapat melanjutkan pendidikannya di perguruan tinggi tatap muka;

3. Mengembangkan program pendidikan akademik dan profesional sesuai dengan kebutuhan nyata pembangunan yang belum banyak dikembangkan oleh perguruan tinggi lain.

Untuk memberikan layanan pembelajaran jarak jauh di setiap provinsi atau kabupaten dan kota di seluruh Indonesia, UT memiliki Kantor Regional yang disebut dengan Unit Program Belajar Jarak Jauh (UPBJJ). Unit Program Belajar Jarak Jauh (UPBJJ) adalah unit pelaksana teknis di daerah. Adapun fungsi dan tugas UPBJJ-UT adalah sebagai tempat mahasiswa untuk melakukan kegiatan administratif akademik dan kegiatan akademik. Untuk kegiatan sehari-hari, UPBJJ-UT mempunyai tugas penyelenggaraan pelayanan belajar jarak jauh. UPBJJ-UT Bandung merupakan salah satu UPBJJ yang diberikan kepercayaan oleh UT Pusat untuk mengelola pemberian beasiswa Bidikmisi. Pada mana masa registrasi 2013.2 UPBJJ UT Bandung mengelola 94 siswa beasiswa bidikmisi dengan rincian seperti pada Tabel 1.

Table 1. Mahasiswa Beasiswa Bidikmisi di UPBJJ UT Bandung

\begin{tabular}{|c|c|}
\hline Program Studi & Jumlah Mahasiswa \\
\hline Akuntansi & 22 \\
\hline Biologi & 23 \\
\hline Perencanaan Wilayah dan Kota & 49 \\
\hline
\end{tabular}

Dalam menjalani proses belajar, mahasiswa UT diharapkan dapat belajar secara mandiri. Cara belajar mandiri menghendaki mahasiswa untuk belajar atas prakarsa atau inisiatif sendiri. Belajar mandiri dapat dilakukan secara sendiri ataupun berkelompok, baik dalam kelompok belajar maupun dalam kelompok tutorial. UT menyediakan bahan ajar yang dibuat khusus untuk dapat dipelajari secara mandiri. Metode belajar mandiri ini berarti bahwa seorang siswa belajar atas inisiatif dirinya sendiri . 
UT menyediakan bahan belajar yang dirancang khusus untuk belajar mandiri. Selain menggunakan bahan yang disediakan oleh UT, mahasiswa juga dapat mengambil inisiatif untuk memanfaatkan perpustakaan, mengikuti tutorial, apakah tatap muka atau melalui internet, siaran radio atau televisi, atau menggunakan bahan ajar berbantuan komputer dan audio/video. Ketika dihadapkan dengan kesulitan dalam belajar, siswa dapat meminta informasi atau bantuan tutorial di UPBJJ UT setempat.

Dalam banyak kasus, belajar mandiri ditentukan oleh kemampuan belajar secara efisien yang tergantung pada kecepatan membaca dan kemampuan untuk memahami materi. Mahasiswa UT yang ingin belajar secara efisien perlu memiliki disiplin diri, inisiatif, dan motivasi yang kuat untuk belajar. Mahasiswa juga diminta untuk menggunakan waktu mereka secara efektif sehingga mereka dapat belajar secara teratur sesuai dengan jadwal mereka sendiri.

Motivasi dalam bahasa latin disebut juga movere, yang berarti bergerak (move) yang artinya motivasi berasal dari kata motif yang artinya dorongan yang datang dari dalam untuk berbuat. Motivasi menjelaskan apa yang membuat orang melakukan sesuatu, membuat mereka tetap melakukannya, dan membantu mereka dalam menyelesaikan tugas-tugas. Hal ini berarti bahwa konsep motivasi digunakan untuk menjelaskan keinginan berperilaku, arah perilaku (pilihan), intensitas perilaku (usaha, berkelanjutan), dan penyelesaian atau prestasi yang sesungguhnya (Pintrich, 2003). Karena itu motif diartikan sebagai kekuatan yang terdapat dalam diri organisme yang mendorong untuk berbuat atau merupakan driving force (Walgito dan Bimo, 2004).

Hakikat motivasi belajar menurut Uno (2009) adalah dorongan internal dan eksternal pada siswa-siswa yang sedang belajar untuk mengadakan perubahan tingkah laku, pada umumnya dengan beberapa indikator atau unsur yang mendukung. Indikator motivasi belajar yang dijelaskan oleh Uno (2009) dapat diklasifikasikan sebagai berikut:

a. Adanya hasrat dan keinginan berhasil.

b. Adanya dorongan dan kebutuhan dalam belajar.

c. Adanya harapan dan cita-cita masa depan.

d. Adanya penghargaan dalam belajar.

e. Adanya kegiatan yang menarik dalam belajar.

f. Adanya lingkungan belajar yang kondusif, sehingga memungkinkan seseorang siswa dapat belajar dengan baik.

Menurut Sardiman (2000) fungsi motivasi belajar ada tiga yakni sebagai berikut:

a. Mendorong manusia untuk berbuat

Sebagai penggerak atau motor yang melepaskan energi. Motivasi dalam hal ini merupakan motor penggerak dari setiap kegiatan yang akan dikerjakan.

b. Menentukan arah perbuatan

Yakni ke arah tujuan yang hendak dicapai. Dengan demikian motivasi dapat memberikan arah dan kegiatan yang harus dikerjakan sesuai dengan rumusan tujuannya.

c. Menyeleksi perbuatan

Yakni menentukan perbuatan-perbuatan apa yang harus dikerjakan yang serasi guna mencapai tujuan, dengan menyisihkan perbuatan yang tidak bermanfaat dengan tujuan tersebut.

Kemandirian belajar menurut Wayne $\mathrm{H}$ adalah menekankan sisi-sisi menguntungkan dari usaha bekerja secara kreatif atas prakarsanya sendiri, inisiatif dan panjang akal dari keadaan mempelajari suatu bidang secara intensif, pengembangan disiplin diri, dan belajar teknik-teknik didalam suatu bidang yang telah dipilihnya sendiri (dalam Kartadinata, 2001). Kemandirian belajar menurut Wragg E.C adalah suatu proses dimana mahasiswa mengembangkan keterampilan- 
keterampilan penting yang memungkinkannya menjadi pelajar yang mandiri, mahasiswa dimotivasi oleh tujuannya sendiri, imbalan dari proses belajar bersifat intrinsik atau nyata bagi mahasiswa dan tidak tergantung sistem luar untuk pemberian imbalan jerih payah belajarnya, dosen hanya merupakan sumber dalam proses belajar, tetapi bukan pengatur atau pengendali (dalam Kartadinata, 2001).

Dalam sintesis kemandirian belajar terdapat dimensi pengelolaan belajar, tanggung jawab, dan pemanfaatan berbagai sumber belajar, sebagai berikut (dalam Izhar dan Encang, 2006).

1. Dimensi pengelolaan belajar berarti peserta ajar harus mampu mengatur strategi, waktu, dan tempat untuk melakukan aktivitas belajarnya seperti membaca, meringkas, membuat catatan dan mendengarkan materi dari audio. Pengelolaan belajar itu sangat penting. Peserta ajarlah yang secara otonom menentukan strategi belajar yang digunakan, kapan ia menggunakan waktu belajarnya, dan di mana ia melakukan proses pembelajarannya tanpa diperintah oleh orang lain. Kemampuan mengelola proses pembelajaran dapat membantu peserta ajar untuk berhasil dalam belajar.

2. Dimensi tanggung jawab berarti peserta ajar mampu menilai aktivitas, mengatasi kesulitan, dan mengukur kemampuan yang diperoleh dari belajar. Dalam belajar mandiri peserta ajar dituntut untuk memiliki kesiapan, keuletan, dan daya tahan. Sehingga diperlukan motivasi belajar yang tinggi. Kesulitan yang dialami dalam belajar harus mereka atasi sendiri dengan mendiskusikan sesama peserta ajar dengan memanfaatkan sumber belajar yang terkait dengan bahan ajar dan memperbanyak latihan soal yang dapat meningkatkan pemahaman peserta ajar. Disamping itu,peserta ajar harus mengukur kemampuan yang diperoleh dari hasil belajar bila hasil belajarnya tidak memuaskan dengan memperbaiki cara belajar dan secara rutin mengerjakan latihan soal.

3. Dimensi pemanfaatan berbagai sumber belajar berarti peserta ajar dapat menggunakan berbagai sumber belajar seperti modul, majalah, kaset audio, VCD, Computer Assested Instructional (CAI), internet, dan tutor. Peserta ajar secara leluasa menentukan pilihan sumber belajar yang diinginkan. Kebebasan peserta ajar dalam memilih berbagai sumber belajar diharapkan dapat memperkaya pemahaman terhadap bahan ajar.

Kemandirian belajar menurut Kartadinata (2001) mempunyai 5 aspek dan dapat dijadikan indikator, antara lain:

1. Bebas bertanggung jawab dengan ciri-ciri mampu menyelesaikan tugas-tugas yang diberikan tanpa bantuan orang lain, tidak menunda waktu dalam mengerjakan tugas, mampu membuat keputusan sendiri, mampu menyelesaikan masalah sendiri dan bertanggung jawab ataumenerima resiko dari perbuatannya.

2. Progresif dan ulet, dengan ciri-ciri tidak mudah menyerah bila menghadapi masalah, tekun dalam usaha mengejar prestasi, mempunyai usaha dalam mewujudkan harapannya, melakukan berbagai cara untuk mencapai tujuan dan menyukai hal-hal yang menantang.

3. Inisiatif atau kreatif, dengan ciri-ciri mempunyai kreatifitas yang tinggi, mempunyai ide-ide yang cemerlang, menyukai hal-hal yang baru, suka mencoba-coba dan tridak suka meniru orang lain.

4. Pengendalian diri, dengan ciri-ciri mampu mengendalikan emosi, mampu mengendalikan tindakan, menyukai penyelesaian masalah secara damai, berpikir dulu sebelum bertindak dan mampu mendisiplinkan diri.

5. Kemantapan diri, dengan ciri-ciri mengenal diri sendiri secara mendalam, dapat menerima diri sendiri, percaya pada kemampuan sendiri, memperoleh kepuasan dari usaha sendiri dan tidak mudah terpengaruh oleh orang lain. 
Salah satu keberhasilan program beasiswa bidikmisi dapat dilihat dari prestasi akademik yang dicapai oleh mahasiswa penerima beasiswa bidikmisi. Nilai mahasiswa dinyatakan dalam bentuk huruf $A, B, C, D$, dan $E$. Nilai matakuliah setiap semester diumumkan dalam Daftar Nilai ujian dan diberikan kepada siswa. Daftar Nilai Ujian mengandung nilai mata kuliah yang diikuti oleh siswa dalam satu semester. Dalam Daftar Nilai Ujian terdapat informasi tentang IPK yang merupakan ratarata nilai yang diperoleh dalam setiap semester.

\section{METODE}

Analisis deskriptif persentase digunakan untuk menggambarkan fenomena penelitian yaitu motivasi belajar dan kemadirian belajar mahasiswa Bidikmisi di UPBJJ UT Bandung. Rumus yang digunakan adalah:

Keterangan:

$$
P=\frac{n}{N} \times 100 \%
$$

$P=$ Persentase nilai yang diperoleh

$\mathrm{n}=$ Jumlah skor yang diperoleh

$\mathrm{N}$ = Jumlah seluruh nilai ideal, dicari dengan cara jumlah aitem dikalikan nilai ideal tiap aitem (Ali 1993).

Hasil kuantitatif dari perhitungan dengan rumus tersebut selanjutnya diubah dan ditafsirkan dengan kalimat yang bersifat kualitatif. Variabel motivasi belajar dan kemadirian belajar mahasiswa ditafsirkan secara kualitatif ke dalam lima kriteria. Adapun langkah-langkah untuk menentukan jenjang kriteria tersebut dilakukan dengan cara sebagai berikut:

a. Menetapkan persentase maksimal yaitu (5:5) x 100\% $=100 \%$

b. Menetapkan persentase minimal yaitu $(1: 5) \times 100 \%=20 \%$

c. Menetapkan rentang persentase, Rentang persentase diperoleh dengan cara mengurangi persentase tertinggi (100\%) dengan persentase terendah (20\%) yaitu $80 \%$

d. Menetapkan panjang kelas interval persentase

Panjang kelas interval persentase diperoleh dengan cara membagi rentang persentase dengan banyaknya kriteria. Banyaknya kriteria yang dipakai adalah sejumlah lima kriteria yakni sangat tinggi, tinggi, sedang, rendah, sangat rendah sehingga panjang kelas interval persentasenya adalah $80 \%: 5=16 \%$.

e. Menetapkan jenjang kriteria

Berdasarkan hasil perhitungan dengan tahapan-tahapan tersebut, maka jenjang kriteria penilaian tingkat motivasi belajar dan kemandirian belajar dapat dilihat pada Tabel 2 .

Tabel 2. Kriteria penilaian tingkat motivasi belajar dan kemandirian belajar

\begin{tabular}{cl}
\hline Interval & \multicolumn{1}{c}{ Kriteria } \\
\hline $85 \%-100 \%$ & Sangat Tinggi \\
$69 \%-84 \%$ & Tinggi \\
$53 \%-68 \%$ & Sedang \\
$37 \%-52 \%$ & Rendah \\
$20 \%-36 \%$ & Sangat Rendah \\
\hline
\end{tabular}


Kriteria penilaian tingkat motivasi belajar dan kemandirian belajar pada Tabel 2, dapat mempermudah peneliti dalam menentukan gambaran tingkat motivasi belajar dan kemandirian belajar mahasiswa.

\section{HASIL DAN PEMBAHASAN}

Berdasarkan hasil analisis, diperoleh tingkat motivasi belajar dan kemandirian belajar mahasiswa beasiswa Bidikmisi yang disajikan pada Tabel 3.

Tabel 3. Tingkat Motivasi Belajar dan Tingkat Belajar Mandiri

\begin{tabular}{ccccc}
\hline \multirow{2}{*}{ Kriteria } & \multicolumn{2}{c}{ Motivasi Belajar } & \multicolumn{2}{c}{ Kemandirian Belajar } \\
\cline { 2 - 5 } & Jumlah & Persentase & Jumlah & Persentase \\
\hline Sangat Tinggi & 52 & 55,3 & 16 & 17,02 \\
Tinggi & 42 & 44,7 & 69 & 73,4 \\
Sedang & 0 & 0 & 9 & 9,57 \\
Rendah & 0 & 0 & 0 & 0 \\
Sangat Rendah & 0 & 0 & 0 & 0 \\
\hline
\end{tabular}

Berdasarkan Tabel 3 diketahui bahwa rata-rata tingkat motivasi belajar termasuk dalam kriteria sangat tinggi, sedangkan kemandirian belajar mahasiswa termasuk dalam kriteria tinggi.

Penelitian tentang motivasi belajar mahasiswa beasiswa Bidikmisi, menunjukkan bahwa ratarata tingkat motivasi belajar termasuk dalam kriteria sangat tinggi dengan persentase $55,3 \%$ dan sebesar 44,7\% motivasi belajar mahasiswa beasiswa Bidikmisi di UPBJJ UT Bandung termasuk dalam kriteria tinggi. Banyak faktor yang mempengaruhi kontribusi terhadap pencapaian nilai ratarata siswa, salah satunya motivasi belajar. Motivasi belajar sangat penting dalam proses pembelajaran karena proses belajar membutuhkan interaksi dan partisipasi aktif dari peserta didik untuk berhasil. Mahasiswa BidikMisi adalah mahasiswa terpilih yang memiliki prestasi akademik yang baik, sehingga wajar jika mereka memiliki tingkat motivasi belajar sangat tinggi atau tinggi. Tingkat motivasi belajar mahasiswa beasiswa Bidikmisi di UT UPBJJ Bandung termasuk dalam kriteria sangat tinggi atau tinggi menunjukkan semakin tinggi dorongan dalam diri mereka untuk berprestasi.

Kemandirian belajar mahasiswa beasiswa Bidikmisi di UPBJJ UT Bandung, menunjukkan termasuk dalam kriteria tinggi dengan persentase $73,4 \%$. Sebesar $17,02 \%$ menunjukkan tingkat kemandirian dengan sangat tinggi. Sistem pendidikan jarak jauh yang merupakan prinsip dasar pembelajaran di Universitas Terbuka (UT) mengharuskan peserta didik belajar secara mandiri. Dari hasil tersebut, dapat diketahui bahwa mahasiswa dengan tingkat kemandirian belajar yang berada di kriteria yang sangat tinggi dan tinggi dapat melaksanakan pembelajaran dalam sistem pembelajaran jarak jauh dengan menekankan belajar mandiri dalam proses pembelajaran. Sebesar $9,57 \%$ kemandirian belajar mahasiswa beasiswa BidikMisi di UPBJJ UT Bandung termasuk dalam kriteria sedang. Hal itu menunjukkan bahwa terdapat mahasiswa beasiswa Bidikmisi di UPBJJ UT Bandung kesiapan dari individu yang mau dan mampu untuk belajar dengan inisiatif sendirinya masih kurang.

Tabel 4 menggambarkan prestasi belajar mahasiswa dilihat dari indeks prestasi belajar yang mereka peroleh.

Berdasarkan Tabel 4 diketahui bahwa ada mahasiswa beasiswa Bidikmisi yang memperoleh IPK $<2,75$. Ini berarti bahwa terdapat mahasiswa Bidikmisi yang tidak mematuhi atau memenuhi persyaratan Bidikmisi UT yang menyatakan bahwa IPK mahasiswa Bidikmisi UT harus $\geq 2,75$. 
Tabel 4. IPK Mahasiswa Bidikmisi di UPBJJ UT Bandung

\begin{tabular}{lccc}
\hline Data & Jumlah & Persentase & Nilai \\
\hline Interval IPK & & & \\
$0,00-2,50$ & 34 & $36,2 \%$ & \\
$2,51-2,99$ & 38 & $40,4 \%$ & \\
$3,00-3,50$ & 20 & $21,3 \%$ & \\
$3,51-4,00$ & 2 & $2,1 \%$ & \\
IPK tertinggi & & & 3,85 \\
IPK terendah & & & 1,75 \\
Rata - rata IPK & & & 2,70 \\
\hline
\end{tabular}

Prestasi Belajar mahasiswa beasiswa BidikMisi di UPBJJ UT Bandung ditunjukkan oleh prestasi belajar mereka dimana IPK minimal yang harus dicapai adalah $\geq 2,75$. Pada tahun pertama, prestasi belajar mereka menunjukkan hasil pencapaian yang belum baik belum baik dengan rata-rata $\mathrm{IPK}=2,70$. Dari evaluasi pencapaian prestasi belajar mahasiswa beasiswa BidiMisi, hanya 41,5\% mahasiswa beasiswa Bidikmisi di UPBJJ UT Bandung yang memperoleh prestasi belajar sangat baik dengan ditunjukkan pencapaian IPK $\geq 2,75$. Sementara 58,5\% mahasiswa beasiswa Bidikmisi di UPBJJ UT Bandung tidak menunjukkan prestasi belajar yang baik dengan pencapaian IPK <2,75.

\section{KESIMPULAN}

Berdasarkan hasil penelitian dan pembahasannya, maka dapat diambil suatu simpulan sebagai berikut:

1. Rata-rata tingkat motivasi belajar termasuk dalam kriteria sangat tinggi dengan persentase 55,3\% dan sebesar 44,7\% motivasi belajar mahasiswa beasiswa Bidikmisi di UPBJJ UT Bandung termasuk dalam kriteria tinggi.

2. Kemandirian belajar mahasiswa beasiswa Bidikmisi di UPBJJ UT Bandung, menunjukkan termasuk dalam kriteria tinggi dengan persentase $73,4 \%$. Sebesar $17,02 \%$ menunjukkan tingkat kemandirian dengan sangat tinggi, sebesar 9,57\% kemandirian belajar mahasiswa beasiswa BidikMisi di UPBJJ UT Bandung termasuk dalam kriteria sedang

3. Dari hasil evaluasi prestasi belajar mahasiswa Beasiswa BidkMisi di UPBJJ UT Bandung, dapat disimpulkan hanya 39 mahasiswa yanga mencapai target dan memamatuhi kontrak UT dimana pada semester II IPK harus IPK $\geq 2,75$.

Untuk meningkatkan prestasi belajar mahasiswa beasiswa BidikMisi pada semester berikutnya beberapa hal harus ditindaklanjuti yang harus ditindaklanjuti yaitu :

1. Bimbingan akademik lebih intens dengan berbagai modus pendekatan kepada mahasiswa

2. Mengingatkan mahasiswa tentang konsep sistem pembelajaran jarak jauh dan kemandirian belajar.

\section{REFERENSI}

Ali, M. (1993). Strategi penelitian pendidikan. Bandung: Angkasa.

Kartadinata, S. (2001). Kemandirian belajar dan orientasi nilai mahasiswa. Bandung: PPS. Sardiman, A.M. (2000). Interaksi dan motivasi belajar mengajar. Jakarta Grafindo Persada.

Uno H B. (2009). Model pembelajaran menciptakan proses belajar mengajar yang kreatif dan efektif. Pontianak: Sinar Grafika Offset.

Walgito, Bimo. (2004). Pengantar psikologi umum, Andi, Yogyakarta. 